University of New Hampshire

University of New Hampshire Scholars' Repository

\title{
Climate change at the ecosystem scale: a 50-year record in New Hampshire
}

\author{
Steven P. Hamburg \\ Brown University \\ Matthew A. Vadeboncoeur \\ University of New Hampshire, matt.vad@unh.edu \\ Andrew D. Richardson \\ University of New Hampshire, andrew.richardson@unh.edu \\ Amey S. Bailey \\ USDA Forest Service
}

Follow this and additional works at: https://scholars.unh.edu/ersc

Part of the Ecology and Evolutionary Biology Commons, and the Forest Sciences Commons

\section{Recommended Citation}

Hamburg, S.P., M.A. Vadeboncoeur, A.D. Richardson, and A.S. Bailey. 2013. Climate change at the ecosystem scale: a 50-year record in New Hampshire. Climatic Change 116 (3-4): 457-477.

This Article is brought to you for free and open access by the Institute for the Study of Earth, Oceans, and Space (EOS) at University of New Hampshire Scholars' Repository. It has been accepted for inclusion in Earth Systems Research Center by an authorized administrator of University of New Hampshire Scholars' Repository. For more information, please contact Scholarly.Communication@unh.edu. 


\title{
Climate change at the ecosystem scale: A 50-year record in New Hampshire
}

\author{
Steven P. Hamburg \\ Environmental Defense Fund \\ Matthew A. Vadeboncoeur \\ University of New Hampshire \\ Andrew D. Richardson \\ Harvard University \\ Amey S. Bailey \\ USDA Forest Service
}

\begin{abstract}
Observing the full range of climate change impacts at the local scale is difficult. Predicted rates of change are often small relative to interannual variability, and few locations have sufficiently comprehensive long-term records of environmental variables to enable researchers to observe the fine-scale patterns that may be important to understanding the influence of climate change on biological systems at the taxon, community, and ecosystem levels. We examined a 50-year meteorological and hydrological record from the Hubbard Brook Experimental Forest (HBEF) in New Hampshire, an intensively monitored Long-Term Ecological Research site. Temperature trends were most significant among examined climate metrics (ranging from 0.7 to 1.3 으 $\mathrm{increase}$ over 40-50 year records at 4 temperature stations), while analysis of precipitation and hydrologic data yielded mixed results. Regional records show generally similar trends over the same time period, though longer-term (70-102 year) trends are less dramatic. Taken together, the results from HBEF and the larger regional records indicate that the climate has warmed detectably at HBEF over 50 years, with important consequences for hydrological processes. Understanding its effects on ecosystems will require a diversity of metrics and concurrent ecological observations at a range of sites, as well as a recognition that ecosystems have existed in a directionally changing climate for decades, and are not necessarily in equilibrium with the current climate.
\end{abstract}

This reformatted accepted manuscript is made available by the authors in accordance with Springer's author rights policy.

The original publication is available at www.springerlink.com; http://dx.doi.org/10.1007/s10584-012-0517-2

This document should be cited as:

Hamburg, S.P., M.A. Vadeboncoeur, A.D. Richardson, and A.S. Bailey. 2013. Climate change at the ecosystem scale: a 50-year record in New Hampshire. Climatic Change 116 (3-4): 457-477. 


\section{Introduction}

To better understand the effects of past and future climate change on ecosystems, we must first examine trends in changing climatic variables and their effects on physical and biological processes critical to ecosystem functioning. Climate models cannot resolve climate-ecosystem interactions at all biologically or ecologically relevant scales, given the complexity of real-world landscapes and their dependence on spatially variable histories of disturbance. Some predictions made at the regional scale may not represent trajectories at specific wellstudied locations, (conversely, no single location is likely to adequately represent the region). Therefore, existing empirical data are of critical importance, as they allow us to examine interactions among diverse climate variables in real-world ecosystems and thus better understand the effects of climate change on specific taxa, communities, and ecosystem processes, including inputs and outputs of water, nutrients, and carbon.

New England has experienced significant climatic change over the $20^{\text {th }}$ Century, and given its long history of climate observations provides a good study system for understanding the relationship between local and regional trends. For example, mean annual temperature in New England and New York increased about 1.1 o $\mathrm{C}$ over the $20^{\text {th }}$ Century (Trombulak and Wolfson 2004). In New Hampshire, warming appears to have been greater in the southern part of the state than in the north (Keim et al. 2003; Trombulak and Wolfson 2004), and total annual precipitation has increased by approximately $10 \mathrm{~mm}$ per decade over the $20^{\text {th }}$ Century in the northeast (Hayhoe et al. 2007). Winters have warmed more than summers, consistent with the globally observed pattern (Lugina et al. 2004), and the fraction of precipitation falling as snow has decreased (Huntington et al. 2004). Biologically relevant seasonal transitions are also changing, from earlier snowmelt (Hodgkins and Dudley 2006) to a longer frost-free season (Easterling 2002). Leaf-out is occurring earlier throughout the northern hemisphere (Schwartz et al. 2006), as is flowering across many taxa in the northeast (Primack et al. 2004; Houle 2007), and growing season is lengthening significantly (Kunkel et al, 2004, Wolfe et al., 2005; Richardson et al., 2006). Similarly, longterm records show trends toward earlier ice-out dates on lakes and rivers across the northeast (Hodgkins et al. 2002; Huntington et al. 2003), and reduced duration of snowcover (Burakowski et al. 2008).

Over the $21^{\text {st }}$ Century, models predict a dramatic warming trend in the northeastern United States, with modest increases in total precipitation.

Christensen et al. (2007) averaged 21 models to predict approximately 3.5-4으 of warming and a 5$10 \%$ increase in precipitation in New England over the $21^{\text {st }}$ century, with greater changes in the winter than in the summer. Easterling et al. (2000) and Schär et al. (2004) report evidence of increases in the frequency of extreme climate events globally and climate modeling indicates a likely increase in the frequency and intensity of extreme events at the extremes of previously established frequency distributions (including drought) in the northeastern U.S. (Wehner, 2004, Tebaldi et al., 2006; Hayhoe et al., 2007).

\subsection{Question and Hypotheses}

Here, we test whether the 50-year climate record at Hubbard Brook Experimental Forest matches modeled changes for the $21^{\text {st }}$ century - a warmer, wetter, more variable climate. We also hypothesize that trends in directly measured climate data (air temperature, precipitation) will be reflected by trends in ecologically relevant derived variables (e.g. degree day metrics) and measurements of variables that are driven by both temperature and precipitation (e.g. evapotranspiration, soil frost). If the existing 50-year record of climatic change qualitatively matches expected future change, there may be important lessons to be learned from the changes observed in the existing long-term ecosystem process datasets of the Hubbard Brook Ecosystem Study. These expected trends include:

- Increased mean annual temperature

- Increased mean seasonal temperatures (summer and winter)

- Increased maximum and minimum annual temperatures

- Increased annual total growing degree-days

- Increased winter thawing degree-days

- Increased length of the frost-free growing season

- Increased total annual precipitation

- Increased length of periods without measurable precipitation 
- Increased frequency of days with intense precipitation

- Increased frequency of extreme high and low streamflow

- Increased total annual evapotranspiration

- $\quad$ Earlier spring thaw streamflow conditions

- Decreased duration of snowpack

- $\quad$ Decreased maximum snow pack water content

- Increased soil frost (as a consequence of reduced snowpack)

While a variety of studies, including those cited above, have examined many of these variables in distributed regional and national data sets, we take a different approach, examining a comprehensive hydrometerologic data set from a single study site, which may provide insight into interactions among processes that averaged data from regional networks would obscure. We ask whether the hypothesized and regionally-observed changes are detectable in the 50-year hydrological and meteorological records from one intensively monitored forest ecosystem, and compare the trends observed at the local scale to other local stations with similar data sets to determine whether trends are representative regionally. While problems with long-term changes in some climate data networks have been resolved (e.g. the Historic Climatology Network maintained by NOAA; see Keim et al. 2003), comparison with highly complete records from a small number of stable sites in the region with a documented lack of changes in landcover, instrumentation, and methodology may provide additional confidence in observed trends. The long-term maintenance of high-quality hydrological and meteorological records across a single, large and intensively studied ecological research site provides a unique opportunity to investigate the influence of concurrent changes in multiple dimensions of climate on ecosystem processes.

\subsection{Site Description}

The Hubbard Brook Experimental Forest (HBEF) was established in 1955 for the study of forest hydrology. The 3160 ha forest (435ㅇ' $\mathrm{N}, 71^{\circ}-45^{\prime} \mathrm{W}$ ) is located in the White Mountain region of New Hampshire (Fig. 1a). Native peoples never lived in the valley, so selective cutting circa 1900 represents the only major historic disturbance. Today the forest is dominated by American beech (Fagus grandifolia Ehrh.), sugar maple (Acer saccharum Marsh.), and yellow birch (Betula alleghaniensis Britt.), transitioning to balsam fir (Abies balsamea L.) and red spruce (Picea rubens Sarg.) at the ridge tops. Eastern hemlock (Tsuga canadensis L.) is important at the lowest elevations (Schwarz et al. 2001). Existing research on forest processes (Likens and Bormann 1995) and high-quality long-term climate records (Bailey et al. 2003) make HBEF an ideal place to study the effects of a continuously changing climate on ecosystem structure and function in the northern hardwood forest. Recent work, for example, has focused on snowpack and soil frost (Groffman et al. 2001; Campbell et al. 2010), the response of canopy structure and composition to a severe ice storm (Rhoads et al. 2002; Weeks et al. 2009), climatic drivers of variation in tree phenology (Richardson et al. 2006) and winter injury in red spruce (Hawley et al. 2006).

\section{Data and Methods}

Meteorological data are collected continuously at the HBEF using standard methods and simple mechanical instruments with proven reliability in harsh environmental conditions. All instruments are visited weekly ensuring that the instruments are well maintained and that problems, when they do occur, are short-lived. The data-collection network currently includes 24 precipitation collectors (those used in this study are mapped in Fig. 1a). Hygrothermographs housed in standard shelters (Fig. 1b) are co-located with seven of the precipitation collectors (Bailey et al. 2003). A realtime network with electronic probes and radio transmission has recently been established, to eventually replace historic measurement techniques. The network is currently in a period of calibration and observation with co-located instruments for data quality assurance. Data used here are from original instruments that have undergone consistent and routine calibration and data processing procedures, and span from the start of each record in the 1950's or 1960's through 2005. The headquarters site (G22) has a more dynamic recent land-use history (building expansion, road paving, and parking lot expansion) than the other studied locations, which may affect the integrity of the record. There are nine gauged watersheds; continuous stream-height measurements are made in a stilling well attached to a V-notch weir at the 
bottom of each watershed; each weir has been calibrated to measured flow rates (Bailey et al. 2003). As a general rule, we selected the longest available records that were not affected by experimental manipulation (e.g. forest cutting) for trend analysis.

\subsection{Temperature}

We analyzed temperature records from the four longest-running meteorological stations at HBEF (Table 1, Fig. 1a). For each station, we calculated the annual mean temperature, based on daily means (reported as the mean of the daily minimum and daily maximum temperatures). Annual means were calculated on a calendar-year basis. Seasonal means were calculated on a calendar-month basis (DJF, MAM, JJA, SON), so that the mean winter value of one year includes December of the previous year. Annual minimum and maximum temperatures were also determined.

We also derived secondary temperature-based climate metrics, including the annual total number of growing degree days (GDD; the annual sum of the difference between each day's mean temperature and a base temperature of 4으; Richardson et al. 2006) in each calendar year, thawing degree-days (TDD; from a base temperature of $0 \circ \mathrm{C}$ ) for the periods December-March and January-February, as well as the dates of the first and last frost each year.

\subsection{Hydrological Cycle}

We examined precipitation data from $\mathrm{W} 3$, a southwest-facing watershed used as the hydrologic reference at $\mathrm{HBEF}$, and W7, which has the longest record among the north-facing watersheds (Table 1 ). Precipitation for each watershed is calculated as a Thiessen-polygon weighted mean of precipitation collected at rain gauges within and near each watershed (Fig. 1a; Bailey et al. 2003). We summed precipitation on a calendar year basis. Though we did not have a specific directional-change hypothesis to test (Hayhoe et al. 2007), we also tabulated summer precipitation (June through August), the period when evapotranspirative flux is greatest, and major ecosystem processes (e.g., photosynthesis, soil respiration) are most likely to be water-limited. We also analyzed the shorter precipitation record at $\mathrm{G} 22$, which receives less precipitation than the experimental watersheds due to its lower elevation and topographic position.

The daily precipitation record allowed us to analyze the timing of precipitation in addition to the annual total. For each calendar year, we tabulated the number of days with $\geq 50 \mathrm{~mm}$ in total precipitation, and determined the length of the longest period in each year with no recorded daily rainfall greater than $1 \mathrm{~mm}$.

Total annual streamflow data from W3 were analyzed on a calendar year basis between 1959 and 2005, and from W7 between 1966 and 2005. For each calendar year, we calculated the number of days with $\geq 50 \mathrm{~mm}$ in total streamflow (the convention at HBEF is to express streamflow volume divided by the area of the contributing watershed, so that it can be directly compared to precipitation data in $\mathrm{mm}$ ), and length of the longest period during which daily streamflow did not exceed $0.1 \mathrm{~mm} \mathrm{day}^{-1}$.

We analyzed the timing of spring melt-influenced streamflow conditions following the center-ofvolume date methodology used by Hodgkins et al. (2003). For each year, we calculated the total January-May streamflow, and identified the date at which half the total volume had passed the weir.

Having both precipitation (water input) and streamflow (water output) for the same watershed allows us to estimate evapotranspiration, an output which can otherwise be measured only using eddy covariance methods (which are unsuitable for the steep topography at HBEF). This method assumes that ecosystem water storage (soil water and snowpack) is the same at the beginning and end of each measured period. High interannual variation in snowpack water content and persistence is the reason a June 1 water year is traditionally used at HBEF. Over many years any errors in storage must approximately cancel, making this method appropriate for examining long-term trends. We calculated evapotranspiration at W3 and W7 for water years beginning June 1 .

\subsection{Snowpack and Soil Frost}

Snow course transects are located near several rain gauges in the watersheds, with the longest continuous record at G2 (Fig. 1; Table 1). Snow is sampled for depth and water content with a Mount Rose snow tube each week during the winter. Snow surveys begin as soon as there is $6^{\prime \prime}(\sim 15 \mathrm{~cm})$ of snow that is expected to remain all winter, and continue as long as there are patches of snow to measure. Each week, 10 measurements of the snow pack are made every two meters along a transect, and are averaged. An entry of 0 indicates no snow at any of the 10 sampling points on the transect; when snow 
is patchy, zero values are included in the average. We analyzed the maximum observed snow water content recorded each winter, as well as the period of snow cover. Data on the presence or absence of soil frost are also taken each time snow is measured; we analyzed the maximum soil frost occurrence observed each winter.

\subsection{Regional and Global Data}

To determine how consistent HBEF data were with records taken elsewhere in the region, and to provide a longer-term context for interpreting trends, we examined long-term temperature records from other weather stations in the White Mountain region (Fig. 1a; Table 1). We included temperature data from three sites: Mt. Washington (47 km NE of HBEF), the highest peak in the northeastern United States; Pinkham Notch (50 km NE of HBEF), a midelevation location; and Hanover, $(50 \mathrm{~km} \mathrm{SW}$ of HBEF), which has an exceptionally long and complete temperature record. We calculated annual and seasonal mean temperatures for each station using the same methods we applied to the HBEF data. However, as these datasets were less complete than those from HBEF (Table 1), we excluded any year with $>10$ days missing data. In years with $\leq 10$ days missing, missing maximum and minimum daily temperatures were linearly interpolated before calculating daily mean temperatures.

Additionally, we examined temperature records in the context of two broader data sets. As an indicator of regionally integrated trends, we extracted annual and seasonal mean data from 1901-2002 for the grid cell centered on 43.75N, 72.750W from a global dataset (Mitchell and Jones 2005). These values were calculated using a weighted mean of all stations located within 1200 $\mathrm{km}$ of the pixel. We also examined the global annual and seasonal mean temperature record for the 3060 oN latitude band (Lugina et al. 2004). To facilitate comparison, all temperature data were normalized to represent deviations from the 1991-1996 mean, the longest recent period for which all records were complete.

The analysis of spring streamflow center-of-volume date was performed on 101 years of gage data (1904-2004) from the Pemigewasset River at Plymouth (USGS-01076500, 4346'N 71이'W), which drains a $1610 \mathrm{~km}^{2}$ watershed, including the HBEF (Table 1).

\subsection{Statistics}

We used a non-parametric Mann-Kendall test to detect trends (Helsel and Hirsch 1992). This test does not require normally distributed data, but does assume (as does ordinary least-squares regression) there is no significant autocorrelation in the time series. We confirmed this with a Durbin-Watson test, which indicated that model residuals were not significantly autocorrelated for any time series (though any long-term persistence is not accounted for, resulting in potentially smaller-than-justified $p$ values; Cohn and Lins 2005). The rate of change in each variable was determined with the Sen slope, a non-parametric estimate of the rate of change in a variable over time. It is attractive for this kind of analysis because it requires fewer assumptions than, for example, least-squares regression, and is relatively insensitive to outliers. The Sen slope is the median slope among all pairs of points in the dataset (Gilbert 1987). A custom SAS program (Winkler 2004) was used for the Mann-Kendall and Sen slope analyses. All analyses were done both for the entire length of the record, and also for the period 19662005, which allows direct comparison among all HBEF records, some of which began as late as 1966 . Trends for both periods are expressed per decade. Where trends were small in magnitude and there were a large number of data ties among years (e.g. for metrics that were counts of days with given conditions), confidence intervals were often not meaningful and are not reported. Due to a large number of years with no observed soil frost, the soil frost record was analyzed using linear least-squares regression, despite its acknowledged limitations. Trends with $p<0.10$ were considered significant, though trends with $p<0.05$ were tallied separately.

Temperature at G1 and streamflow for W3 were analyzed using a frequency distribution approach. These are the longest-term records of their respective types that are not subject to experimental manipulation (forest cutting or fertilization). Temperature data were classed into 5 으 $\mathrm{C}$ bins and the daily streamflow (in $\mathrm{mm} /$ day) was classed into 20 bins on a logarithmic scale. We compared the frequency distribution of the 20 -year period at the beginning of the record (1958-1977) to that of the 20-year period at the end of the record (1986-2005). Differences between the two time periods are expressed as percent change in frequency in each class. 


\section{Results}

\subsection{Temperature}

The four HBEF temperature records examined are highly correlated in mean annual temperature (Fig. 2a). The offset among these sites is largely a factor of elevation; the lapse rate calculated using $\mathrm{G} 1$ and $\mathrm{G} 6$ is $-5.2^{\circ} \mathrm{C} / 1000 \mathrm{~m}$ and shows no detectable trend over time. Three of the four stations showed significant increases in mean annual temperature over the entire available record; trends ranged from $0.13-0.32$ o $\mathrm{C} /$ decade (Fig. 2a; Table 2 ). When only the 1966-2005 record was examined, three of four were still significant, and the mean trend was $0.21 \pm 0.08 \div \mathrm{C} /$ decade $(95 \% \mathrm{Cl})$. Over both time periods, G14 had the strongest trend, while G1 and $\mathrm{G} 6$ had the weakest. Over the last 40 years of the record, trends observed at HBEF are similar to those seen elsewhere in the region and globally (Fig. 2). Pearson's correlation coefficients $(r)$ between G1 and regional records range from 0.83 (Pinkham Notch) to 0.88 (Mt. Washington), while correlation with the global record $(r=0.52)$ is poorer. Observed changes in mean annual temperature at HBEF (0.130.32 per decade in the $40-50$ years leading up to 2005) are decidedly greater than the longer-term regional data we examined (Table 2 ), and are also greater than the $\sim 0.04-0.1 \mathrm{o} /$ decade trends observed in NH from 1931-2000 (Keim et al. 2003) and the $\sim 0.12 \mathrm{o} /$ /decade trend observed over the full $20^{\text {th }}$ century (Trombulak and Wolfson 2004) using statewide networks of stations.

Examined individually, records of mean seasonal temperatures often look very different from mean annual temperatures (Table 2). At HBEF, mean winter temperatures (G1 stdev for 1996-2005=1.80 ${ }^{\circ} \mathrm{C}$ ) are more variable than are summer temperatures (G1 stdev for $1996-2005=0.74^{\circ} \mathrm{C}$ ). Trends for mean winter and mean summer temperatures are each significant at three of the four stations examined (Table 2), and rates of winter warming over the past 40 years $(0.31$ -

0.45 으/decade) are non-significantly greater than rates of summer warming $\left(0.02-0.33^{\circ} \mathrm{C} /\right.$ decade) at all sites except G22 at the headquarters building. This difference is consistent in pattern with the findings of Burakowski et al. (2008) who documented a similar rate of winter warming $\left(0.43^{\circ} \mathrm{C} /\right.$ decade $)$ in the northeast over a similar time period (1965-2005). Hayhoe et al. (2007) also observed greater warming in winter than summer in
New England from 1970-2000, though the increases were smaller in magnitude.

Of the four temperature records at HBEF, only G22 showed a significant increase in maximum annual temperature $\left(0.52^{\circ} \mathrm{C} /\right.$ decade between 1957 and $2005, p<0.01)$. This could be the result of increasing the extent of paving in the immediate surrounding area. Minimum annual temperature only increased significantly at G14 (1.24으/decade between 1965 and 2005, $p=0.03)$. Overall temperature extremes are a stochastic metric, and it is not surprising that few statistically significant trends were observed.

Annual growing degree days (GDD) increased significantly in three of four HBEF temperature records examined. The mean slope was 32.6 GDD/decade between 1966 and 2005. Thawing degree days (TDD) have increased significantly at G1 both in January-February and December-March (Fig. 3). When the 1956-2005 record is examined, the slope is +2.9 TDD/decade for January and February alone, and 10.5 TDD/decade for December-March. The length of the frost-free growing season has increased significantly at $\mathrm{G} 1$, by 3.75 days/decade between 1956 and 2005 ( $p=0.03$ ). This result is driven both by a later date of the first autumn frost ( 1.9 days/decade, $p=0.04$ ) as well as a non-significantly earlier date for the last spring frost (1.6 days/decade, $p=0.15$ ).

\subsection{Precipitation and Hydrology}

No significant trend was observed for total annual precipitation at either W3 or W7, though the nonsignificant trends were both positive (note that a prolonged drought occurred in the early 1960s, but was over by the start of the W7 record in 1966). Summer precipitation showed a significant trend (17.1 mm/yr/decade) in W3 between 1958 and 2005 , but the trend was not significant between 1966 and 2005, or at W7. There were no significant changes in the length of each year's longest precipitation-free period, and the frequency of days with $>50 \mathrm{~mm}$ of precipitation increased significantly at W7 but not at W3.

The frequency of days with low streamflow $(<0.1$ $\mathrm{mm}$ daily) at W3 decreased significantly between 1958 and 2005 (-8.7 days/yr/decade, $p<0.01$ ). A very small but significant increase in the frequency of days with intense precipitation ( $>50 \mathrm{~mm}$ daily) occurred at W7. Evapotranspiration decreased significantly at W3 $(-10.9 \mathrm{~mm} / \mathrm{yr} /$ decade, $p=0.01)$ but not at W7. 
Spring streamflow center-of-volume date has become significantly earlier at W3 (2.1 days earlier per decade over 1958-2005) and at W7 (3.1 days earlier per decade over 1966-2005), though the trend was not significant in the 1966-2005 record from W3 (Table 1; Fig. 4). The mean spring centerof-volume date from these two first-order watersheds correlates remarkably well with those from the Pemigewasset River at Plymouth ( $r=0.94)$, despite the fact that the watersheds differ in area by a factor of more than three orders of magnitude and in elevation range by a factor of $>5$ (Table 1 ). Spring center-of-volume date on the Pemigewasset has not changed significantly over the entire 101-year records, but its trend since 1966 is similar to those at HBEF, (1.9 days/decade earlier).

\subsection{Snowpack and Soil Frost}

The observed trend in date of first measurable snowpack each season, 1.7 days later/decade was not significant, while the date of last measurable snowpack in spring has become significantly earlier at a rate of 2.5 days/decade, for a significant net reduction by 4.2 days/decade in the snowpack duration ( $p=0.06)$. Regionally, Burakowski et al. (2008) found a similar reduction in snowpack duration (3.6 days/decade), as well as significantly reduced total snowfall, which we did not examine. Maximum snowpack water content at G2, the only long-term record of its kind at HBEF, decreased significantly between winters 1956 and 2006, with a slope of $-10.5 \mathrm{~mm} /$ decade (about $-5 \% /$ decade; $p=0.08)$.

Soil frost coverage is expected to be negatively correlated with snowpack depth and water content, but is highly variable both spatially and interannually. No soil frost was observed at G2 between 1965 and 1969, though the sampling intensity during these years is not well documented (we did not include these years in the trend analysis). While widespread frost was not observed at HBEF before 1970, it is not uncommon now (Likens and Bormann 1995; Campbell et al. 2010).

\subsection{Frequency Analyses - Temperature and Runoff}

Frequency distribution of daily mean temperature at G1 (Fig. 5a) and daily total streamflow at W3 (Fig. 5b) shifted observably over the record. In particular, days with a mean temperature of $-25 \pm 2.5$ 으 were $39 \%$ less frequent from 1986-2005 compared to 1958-1977, while days of $25 \pm 2.5$ 으 were $5 \%$ more frequent. The temperature with the greatest increase was $5 \pm 2.5 \circ \mathrm{C}$, which was $10 \%$ more frequent. This temperature occurs most commonly in early spring and mid-autumn, times when organisms are transitioning physiologically and are thus particularly sensitive to swings above and below freezing. The pattern of streamflow at W3 also changed, with low rates becoming less common and high rates becoming more common although it is important to note that this pattern is likely to have been influenced by a severe drought that affected the northeast in 1963-5.

\subsection{Pattern of change}

Out of 18 metrics examined over the past 40-50 years, 13 have changed significantly $(p<0.10)$ in the hypothesized direction in at least one location at HBEF (of which 11 had $p<0.05$ ), while two (evapotranspiration and frequency of low streamflow) have changed significantly in the opposite direction (Table 2). These metrics are not statistically independent (we did not include our one observationally non-independent metric, evapotranspiration, in the count), but demonstrate that a wide variety of climate metrics yield similar qualitative results. Observed trends depend somewhat on the length of record analyzed: measured temperature and temperature-derived trends have larger slopes and greater significance when examined for the period 1966-2005 than for longer time periods. While this result matches with the general observation that global temperatures began rising rapidly in the 1970's (Folland et al. 2001), it is also true that the 1966 start date we selected to compare the maximum length of record across all sites examined (Table 1), anchors the beginning of our time series in an anomalously cold period for the region (Fig 2b). On the other hand, the late-1950's were considerably warmer than either the preceding 50 years or the following 30 years globally and at other regional stations (Fig 2b), and only around 1980 does the start of a clear rising trend become obvious in the longer-term data, which provide important context for interpreting the trends observed in the $40-50$ year records examined at HBEF.

\section{Discussion}

\subsection{Climate shifts}

Changes in frequency distributions of temperature and streamflow (Fig. 5) show that the width of the probability density functions for these two variables have remained approximately constant over the past 
50 years at $\mathrm{HBEF}$, while the means of those distributions have shifted. Put simply, the climate as a whole is becoming warmer, and streamflow is increasing, but the (admittedly variable) extremes do not appear to be changing faster than the means. This finding, while similar to those reported by Frich et al. (2002), who examined 10 climatic parameters at the global scale over the past 50 years, contrasts somewhat with the more mixed findings of largerscale analyses of the frequency of extreme events in some climate metrics (Schär et al. 2004; Tiebaldi et al. 2006; Alexander et al. 2006), though differences among the metrics examined make such comparisons difficult.

\subsection{Changes in the timing of seasonal transitions}

Greater warming in winter and spring than summer has been widely observed in the northern hemisphere (Liu et al. 2007) and can lead to large changes in the timing of ecologically relevant seasonal transitions. For example, streamflow conditions indicative of spring snowmelt advanced 812 days over the 50-year record, similar to the 1-2 week advance observed regionally by Hodgkins et al. (2003). On the other hand, the 18-day advance in ice-out on Mirror Lake (adjacent to HBEF) since the late 1960's (Likens 2009) appears quite dramatic in comparison to the longer record presented by Hodgkins et al. (2002). Along with earlier snowpack melting at G2 (12 days earlier since 1955), these results point to a significantly earlier transition to spring thaw conditions characterized by the availability of liquid water and soil temperatures permitting root activity. The end of the snowpack likely represents a major "tipping point" in the seasonal transition, when surface soil temperature is released from control by the thermal insulation and high albedo of existing snowpack, as well as latent heat loss of the melting snowpack. Following this transition, soils temperatures generally warm rapidly, but are also subject to more dramatic fluctuation, with potential consequences for physical and physiological disturbance to shallow roots and ground-level vegetation.

Similar changes appear to be occurring in the fall as well. Easterling (2002) found that since 1948 the first frost has occurred about 2-3 days later, while the date of last frost has occurred about 5 days earlier throughout the northeast. The HBEF data from G1 for the period 1956-2005 indicate a much larger shift, with first frost occurring 10 days later $(p=0.05)$.
Changes in seasonal timing can affect the growing season utilized by plants. Global data suggest that the onset of the northern hemisphere spring advanced approximately 1 week from the 1970s to 1990s (Keeling et al. 1996), and similar trends are found in studies of budburst and flowering at multiple scales ( 8 days earlier over 100 years in Boston, Primack et al. 2004; 5 to 6 days earlier over 35 years across the US, Schwartz and Reiter 2000). Tree phenology data are collected at HBEF and correlate well with spring temperatures (Richardson et al. 2006). While the 16-year record is insufficient for time-series analysis, they allowed the calibration of a model that estimated a slow trend towards earlier spring ( 0.2 days advance per decade) for the period 1957-2004 (Richardson et al. 2006).

\subsection{Changes in precipitation and streamflow}

While there are some broad trends in the hydrologic record over the last 50 years at HBEF, few are statistically significant (Table 2). This is probably due both to interannual and decadal-scale variation which are large relative to the magnitude of any long-term trend. For example, annual precipitation at W3 ranges from 979-1793 $\mathrm{mm}$, and the observed increase ( $34 \mathrm{~mm}$ annual total per decade) was nonsignificant, but at least generally consistent with the range of trends observed by Lins and Slack (1999), who showed significant increases in streamflow across most of the continental US on streams with multi-decadal records. Streamflow is highly correlated with precipitation, $(r=0.96$ at W3 on a water-year basis).

At HBEF, trends in evapotranspiration were mixed, with a significant decrease at W3 over the full record, and a non-significant increase at W7 since 1966; trends at W3 and W7 did not differ significantly during this period. This result is also unexpected, as warmer and longer growing seasons would be expected to increase, rather than decrease, total annual ET (Huntington et al. 2009). However, a complicating factor is that the forest canopy at HBEF has increased in structural complexity (i.e. spatial variation in maximum height) since the 1950's, due to the aging of the forest, as well as a number of disturbance events (e.g. the 1998 ice storm). Alternatively, the observed decrease in ET may be related to trends in unexamined climatic factors, such as cloudiness, relative humidity, and windiness, for which the records at HBEF are not complete enough to justify trend analysis. Changes in stomatal density and 
regulation related to forest age and structure, atmospheric $\mathrm{CO}_{2}$ concentrations, nutrient availability, and acid deposition in northern hardwood species are other potential explanations for changes in ET, and are the focus of much current research at $\mathrm{HBEF}$ and throughout the region.

Lins and Slack (2005) and McCabe and Wolock (2002) observed increases in the lower end of the flow-volume distribution at both the national and regional scales, which they interpret as due to increased precipitation in the warm (low-flow) months, while high flows have generally not changed significantly. At W3, we observed an unexpected decrease in the frequency of days with low streamflow $(<0.1 \mathrm{~mm})$, precisely the transient conditions in which evapotranspiration might be expected to be water-limited rather than energylimited, sensu Budyko (1974). We did not observe a significant change in the maximum duration of precipitation-free periods which might be expected to contribute such temporary water limitation. These trends (presumed increases in soil water availability as reflected by reduced low-streamflow events, along with decreases in apparent annual evapotranspiration) appear to run counter to each other, unless the factor driving the change in the system is a decrease in evapotranspirative demand. Another un-investigated pathway that may help explain the change in evapotranspiration in light of observed winter warming is snowpack sublimation. It is important to note, however, that none of these trends are significant in the 40-year record (19662005), only in the 50-year record, which includes the unusually dry period of the early 1960's.

\subsection{Vegetation community implications}

Species distributions worldwide have been observed to respond to $20^{\text {th }}$ century climate change (Parmesan and Yohe 2003). Iverson and Prasad (2002) show the potential for dramatic climate-driven shifts in forest species composition in New England by the year 2100 , though range expansions are unlikely to keep up with the expected rate of climate change, and species shifts may be delayed, abrupt, and asynchronous across the landscape (Mohan et al. 2009). The 1 o $C$ of warming in the 50 -year temperature record at $\mathrm{HBEF}$ is equivalent to a drop in elevation of 150-200 m, roughly the elevation range covered by the south-facing experimental watersheds, across which forest composition ranges from northern hardwoods at lower elevations to boreal spruce-fir at higher elevations. Presettlement forest records (Vadeboncoeur et al. 2012) suggest that the hardwood/boreal ecotone has moved $\sim 60$ m upslope in 200 years, due in part to the decline of red spruce, which has been attributed climate change (Hamburg and Cogbill 1988; Beckage et al. 2008). Further upslope encroachment of hardwoods seems likely; on low ranges such as those at Hubbard Brook, spruce-fir forests may be extirpated completely as has been previously suggested (Iverson and Prasad, 2002). Lund and Livington (1999) suggest that spruce damage is brought on by cold temperatures following midwinter thaws that result in the foliage dehardening, rendering it susceptible to frost damage. Hawley et al. (2006) found significant damage in 2003 on W6 at HBEF, in a year when the temperature reached $-26 \circ C$ at $G 6$ only 8 days after a significant thaw. Spruce cold tolerance is also decreased in areas of high $\mathrm{N}$ deposition and low soil Ca (Hawley et al. 2006). The combined effect of increased winter thawing (Fig. 3), and a decrease in the frequency of extreme cold temperatures (Fig. 5a) on red spruce in the future remains unclear, and may depend on future trends in acid deposition.

Other tree species may also be affected by changing patterns of winter temperatures, particularly with regard to specific thresholds and extremes. Changes in snowpack depth and duration, and associated changes in soil frost, seem particularly likely to affect young size classes of trees and evergreen forest herbs. Borque et al. (2005) suggest that yellow birch suffers winter damage when the minimum temperature falls below -4 o $\mathrm{C}$ after experiencing 50 growing degree days in the spring. At G1, at an elevation where yellow birch is abundant at HBEF, 1981 was the year with the greatest potential for yellow birch damage according to these criteria. In fact 1981 saw a major regional dieback of birches and sugar maple (Auclair 2005). However, systemic dieback of yellow birch has not been reported at $\mathrm{HBEF}$, and no trend in the frequency of such events since 1956 is evident in the data from G1. To the extent that spring phenology is determined by accumulated degree days rather than by photoperiod, an earlier and more variable spring might lead to more frequent spring-freeze defoliation events (e.g. Gu et al. 2008); indeed a hard frost in May 2010 following budburst occurred at Hubbard Brook and elsewhere in the northeast, with important effects on carbon balance in several canopy species (Hufkens et al. 2011). Whether such events become more frequent is dependent on the 
rate at which frost-sensitive phenological stages advance relative to the advance in the latest occurrence of damaging cold each spring (Scheifinger et al. 2003); similar interactions may occur with soil freeze-thaw events and root activity. Continued increases in atmospheric $\mathrm{CO}_{2}$ concentration may also mitigate stresses caused by extreme or unusually-timed extreme temperatures (Wayne et al. 1998).

Insects as well as trees may respond to changes in winter climate. The hemlock wooly adelgid, an introduced insect, has decimated hemlock forests in southern New England, but has not yet spread to northern New England. Temperatures of -25ㄷ C are $>98 \%$ lethal to hemlock wooly adelgids (Skinner et al. 2003), yet at G22, at the elevation where hemlock is most important at $\mathrm{HBEF}$, wintertime temperature minima have dropped below -25 ㅇ C in only four of the last 10 years, compared with eight of the first ten years of the record. If such winter warming continues, the adelgid can be expected to expand its range northward toward HBEF in years with warm winters (Evans and Gregoire 2007).

\subsection{Biogeochemical implications}

The effect of a changing climate on ecosystem-level C cycling is likely to be mixed. Campbell et al. (2009) modeled increased primary production due to a longer growing season. However, if severe storms become more frequent (Easterling et al. 2000), or if winter dieback increases or new pathogens invade, there could be a net loss of standing live biomass and a resulting increase in litterfall, which would be rapidly respired particularly under a warmer, wetter climate (Rustad et al. 2001; White and Nemani 2003). Reduced snowpack may or may not increase soil frost in light of warmer winter temperatures (Campbell et al. 2010), perhaps affecting fine root turnover (Groffman et al. 2001). Soil frost and temperature-driven increases in $\mathrm{N}$ mineralization and nitrification may increase nitrate leaching (Groffman et al. 2001; Campbell et al. 2009), transferring $\mathrm{N}$ from terrestrial to aquatic ecosystems, though the long-term trajectory of anthropogenic $\mathrm{N}$ loading on these ecosystems remains uncertain and will interact with the effects of a changing climate on ecosystem processes.

Hollinger et al. (2004) showed that warm spring and autumn temperatures correlated with increased production, while hot summers correlated with decreased production, so the end result of disproportionate winter and transition-season warming might be an increase in ecosystem $C$ storage. Warm springs that lead to early budburst may lead to both immediate and time-lagged effects on ecosystem $\mathrm{C}$ exchange, and increases in production may be greater for deciduous species (Richardson et al. 2009). Huntington (2005) proposed that the Ca status of forested sites in Maine may decline with increased production over a longer growing season, increased base cation leaching from greater rainfall, as well as shifts from spruce and fir to more Ca-demanding hardwoods. Indeed, over the longer term, the indirect effects of climate changes on biogeochemical cycles via species shifts (e.g. spruce and hemlock giving way to deciduous species) will be important to consider.

\subsection{Conclusions}

Ecologically meaningful changes in the climate at HBEF have occurred over the past 50 years, and predicted changes are likely to further alter the forest's community ecology and biogeochemistry. A complete understanding of these changes requires long-term studies at the ecosystem scale where the multiple interacting climatic variables are monitored alongside ecological observations and other changes (e.g. $\mathrm{CO}_{2}$ and $\mathrm{O}_{3}$ concentrations, atmospheric inputs of acidity and nutrients). Inherent in a great deal of ecological research is the assumption that the system is in equilibrium. However, we show here that significant changes in multiple climatic variables have occurred over the 50-year history of ecological research at HBEF. The non-equilibrium status of the current forest ecosystem with respect to climate and other perturbations is an important consideration when examining responses to disturbance, or parameterizing models describing future ecosystem function.

\section{Acknowledgements}

The data presented were collected and processed by dozens of USFS employees, whose careful attention to detail was critical to maintaining the quality of this record. We are grateful to all those involved, especially Wayne Martin, Tony Federer and Jim Hornbeck. We thank Mark Green for helpful discussion regarding hydrologic trends. HBEF is now an NSF-funded Long-Term Ecological Research site, operated by the USFS Northern Research Station. This work was funded by NSF grant 0423259 to SPH, and is a contribution to the Hubbard Brook Ecosystem Study. 


\section{References}

Alexander LV, Zhang X, Peterson TC et al. (2006) Global observed changes in daily climate extremes of temperature and precipitation. Journal of Geophysical Research 111:1-22.

Auclair AND (2005). Patterns and general characteristics of severe forest dieback from 1950 to 1995 in the northeastern United States. Can J For Res 35:1342-1355. doi:10.1139/x05066

Bailey AS, Hornbeck JW, Campbell JL, Eagar C (2003) Hydrometerological database for Hubbard Brook Experimental Forest: 1955-2000. USDA Forest Service, NE Research Station General Technical Report NE-305. http://www.treesearch.fs.fed.us/pubs/5406

Beckage B, Osborne B, Gavin DG, Pucko C, Siccama T, Perkins T (2008) A rapid upward shift of a forest ecotone during 40 years of warming in the Green Mountains of Vermont. Proc Nat Acad Sci 105:4197-202.

Borque CP, Cox RM, Allen DJ, Arp PA, Meng FR (2005) Spatial extent of winter thaw events in eastern North America: historical weather records in relation to yellow birch decline. Glob Change Biol 11:1477-1492.

Budyko MI (1974) Climate and Life. Academic Press.

Burakowski EA, Wake CP, Braswell B, Brown DP (2008) Trends in wintertime climate in the northeastern United States: 1965-2005. J Geophys Res 113: D20114.

Campbell JL, Rustad LE, Boyer, EW, et al. (2009) Consequences of climate change for biogeochemical cycling in forests of northeastern North America. Can J For Res 39:264-284. doi:10.1139/X08-104

Campbell JL, Ollinger SV, Flerchinger GN, Wicklein H, Hayhoe K, Bailey AS (2010) Past and projected future changes in snowpack and soil frost at the Hubbard Brook Experimental Forest, New Hampshire, USA. Hydrol Proc 24:2465-2480.

Christensen JH, B Hewitson A, Busuioc A, et al. (2007) Regional Climate Projections. In: Climate Change 2007: The Physical Science Basis. (eds Solomon S, Qin D, Manning M, Chen Z, Marquis M, Averyt KB, Tignor M, Miller HL). Cambridge University Press, New York.
Cohn TA, Lins HF. 2005. Nature's style: Naturally trendy. Geophys Res. Lett. 32: L23402.

Easterling DR (2002) Recent changes in frost days and the frost-free season in the United States. Bull Am Meteor Soc 83:1327-1332.

Easterling DR, Evans JL, Groisman PY, Karl TR, Kunkel $K E$, Ambenje $P$ (2000) Observed Variability and Trends in Extreme Climate Events: A Brief Review. Bull Am Meteor Soc 81: 417-425.

Evans AM, Gregoire TG (2007) A geographically variable model of hemlock woolly adelgid spread. Biol Invas 9:369-382. Folland CK, Rayner NA, Brown SJ, et al. (2001) Global temperature change and its uncertainties since 1861. Geophys Res Let 28:2621-2624.

Frich P, Alexander LV, Della-Marta P, Gleason P, Haylock M, Klein AMG, Peterson T (2002) Observed coherent changes in climatic extremes during the second half of the twentieth century. Clim Res 19:193-212.

Gilbert RO (1987) Statistical methods for environmental pollution monitoring. Van Nostrand Reinhold, New York.

Groffman PM, Driscoll CT, Fahey TJ, Hardy JP, Fitzhugh RD, Tierney GL (2001) Colder soils in a warmer world: A snow manipulation study in a northern hardwood forest ecosystem. Biogeochemistry 56:135-150.

Gu L, Hanson PJ, MacPost W, Kaiser DP, Yang B, Nemani R, Pallardy SG, Meyers T (2008) The 2007 eastern US spring freeze: increased cold damage in a warming world? Bioscience 58:253-262.

Hamburg SP, Cogbill CV (1988) Historical decline of red spruce populations and climatic warming. Nature 331:428-431.

Hawley GJ, Schaberg PG, Eagar C, Borer CH (2006) Calcium addition at the Hubbard Brook Experimental Forest reduced winter injury to red spruce in a high-injury year. Can J For Res 36:2544-2549.

Hayhoe K, Wake CP, Huntington TG, et al. (2007) Past and future changes in climate and hydrological indicators in the US Northeast. Clim Dyn. 28:381-407.

Helsel DR, Hirsch RM (1992) Statistical methods in water resources. Studies in Environmental Science 49. Elsevier Science, Amsterdam. 
Hodgkins GA, James IC, Huntington TG (2002) Historical changes in lake ice-out dates as indicators of climate change in New England, 1850-2000. Int J Climatol 22: 1819-1827.

Hodgkins GA, Dudley RW, Huntington TG (2003) Changes in the timing of high river flows in New England over the 20th Century. J Hydrol 278:244-252.

Hodgkins GA, Dudley RW (2006) Changes in latewinter snowpack depth, water equivalent, and density in Maine, 1926-2004. Hydrol Proc 20:741-751. doi:10.1002/hyp.6111

Hollinger DY, Aber J, Dail B, et al. (2004) Spatial and temporal variability in forest-atmosphere $\mathrm{CO} 2$ exchange. Global Change Biology 10:1689-1706.

Houle G (2007) Spring-flowering herbaceous plant species of the deciduous forests of eastern Canada and 20th century climate warming. Can J For Res 37:505-512.

Hufkens K, Sonnentag O, Keenan TF, et al (2011) Community impacts of mid-May frost event during an anomalously warm spring. Am Geophys U.

Huntington, TG (2005). Assessment of calcium status in Maine forests: review and future projection. Canadian Journal of Forest Research 35:11091121. doi: 10.1139/x05-034.

Huntington TG, Hodgkins GA, Dudley RW (2003) Historical trend in river ice thickness and coherence in hydroclimatlogical trends in Maine. Clim Change 61:217-236.

Huntington TG, Hodgkins GA, Keim BD, Dudley RW (2004) Changes in precipitation occurring as snow in New England (1949-2000). J Climate 17:26262636.

Huntington TG, Richardson AD, McGuire KJ, Hayhoe $\mathrm{K}$ (2009) Climate and hydrological changes in the northeastern United States: recent trends and implications for forested and aquatic ecosystems. Can J For Res 39:199-212.

Iverson LR, Prasad AM (2002) Potential redistribution of tree species habitat under five climate change scenarios in the eastern US. For Ecol Manage. 155:205-222.

Keeling CD, Chin JFS, Whorf TP (1996) Increased activity of northern vegetation inferred from atmospheric $\mathrm{CO}_{2}$ measurements. Nature 382:146-149.

Keim BD, Wilson AM, Wake CP, Huntington TG (2003) Are there spurious temperature trends in the United States Climate Division database? Geophys Res Lett 30: 1404.

Kunkel KE, Easterling DR, Hubbard K, Redmond K (2004) Temporal variations in frost-free season in the United States: 1895-2000. Geophys Res Lett. 31: L03201. doi:10.1029/2003GL018624Likens GE (2009) A limnological introduction to Mirror Lake. In: Mirror Lake: Interactions among Air, Land, and Water. (eds Winter TC, Likens GE). University of California Press, Berkeley.

Likens GE, Bormann FH (1995) Biogeochemistry of a Forested Ecosystem. New York: Springer-Verlag.

Lins HF, Slack JR (1999) Streamflow trends in the United States. Geophys Res Lett 26: 227-230.

Lins HF, Slack JR (2005) Seasonal and regional characteristics of US streamflow trends in the United States from 1940 to 1999. Phys Geogr. 26: 489-501. doi:10.2747/0272-3646.26.6.489

Liu J, Curry JA, Dai Y, Horton R (2007) Causes of the northern high-latitude land surface winter climate change. Geophys Res Lett 34:L14702.

Lugina KM, Groisman PY, Vinnikov KY, Koknaeva VV, Speranskaya NA (2004) Monthly surface air temperature time series area-averaged over the 30-degree latitudinal belts of the globe, 18812004. Oak Ridge National Laboratory, Oak Ridge, TN.

Lund AE, Livingston WH (1999) Freezing cycles enhance winter injury in Picea rubens. Tree Phys 19:65-69.

McCabe GJ, Wolock DM (2002) A step increase in streamflow in the conterminous United States. Geophys Res Lett 29(24):2185.

Mitchell TD, Jones PD (2005) An improved method of constructing a database of monthly climate observations and associated high-resolution grids. Int J Climatol 25:693-712.

Mohan, JE, Cox RM, Iverson LR (2009) Composition and carbon dynamics of forests in northeastern North America in a future, warmer world. Can J For Res 39:213-230. 
Parmesan C, Yohe G (2003) A globally coherent fingerprint of climate change impacts across natural systems. Nature 421:37-42.

Primack D, Imbres C, Primack RB, Miller-Rushing AJ, Del Tredici P. (2004) Herbarium specimens demonstrate earlier flowering times in response to warming in Boston. Am J Bot 91:1260-1264.

Rhoads AG, Hamburg S, Fahey TJ, et al. (2002) Effects of an intense ice storm on the structure of a northern hardwood forest. Can J For Res 32:1763-1775.

Richardson AD, Bailey AS, Denny EG, Martin CW, O'Keefe J (2006) Phenology of a northern hardwood forest canopy. Glob Change Biol 12:1174-1188.

Richardson AD, Hollinger DY, Dail DB, et al. (2009) Influence of spring phenology on seasonal and annual carbon balance in two contrasting New England forests. Tree Phys 29: 321-31. doi: 10.1093/treephys/tpn040Rustad LE, Campbell JL, Marion GM, et al. (2001) A meta-analysis of the response of soil respiration, net nitrogen mineralization, and aboveground plant growth to experimental ecosystem warming. Oecologia 126:543-562. doi:10.1007/s004420000544

Schär C, Vidale PL, Lüthi D, Frei C, Häberli C, Liniger MA, Appenzeller C (2004) The role of increasing temperature variability in European summer heatwaves. Nature 427:332-336.

Scheifinger H, Menzel A, Koch E, Peter C (2003) Trends of spring time frost events and phenological dates in central Europe. Theor Appl Climatol 74:41-51.

Schwartz MD, Reiter BE (2000) Changes in North American Spring. Int J Climatol 20:929-932.

Schwartz MD, Ahas R, Aasa A (2006) Onset of spring starting earlier across the Northern Hemisphere. Glob Change Biol 12:43-351.

Schwarz PA, Fahey TJ, Martin CW, Siccama TG, Bailey A (2001) Structure and composition of three northern hardwood-conifer forests with differing disturbance histories. For Ecol Manage 144:201212.

Skinner M, Parker BL, Gouli S, Ashikaga T (2003) Regional responses of hemlock woolly adelgid to low temperatures. Environ Entomol 32:523-528.

Tebaldi C, Hayhoe K, Arblaster JM, Meehl GA (2006) Going to the Extremes: an intercomparison of model-simulated historical and future changes in extreme events. Clim Change. 79:185-211.

Trombulak SC, Wolfson R (2004). Twentieth-century climate change in New England and New York, USA. Geophys Res Lett. 31: L19202.

Vadeboncoeur MA, Hamburg SP, Cogbill CV, Sigamura WY (2012) A comparison of presettlement and modern forest composition along an elevation gradient in central New Hampshire. Can J For Res. 41:190-202.

Wayne PM, Reekie EG, Bazzaz FA (1998) Elevated $\mathrm{CO}_{2}$ ameliorates birch response to high temperature and frost stress: implications for modeling climate-induced geographic range shifts. Oecologia 114:335-342.

Weeks BC, Hamburg SP, Vadeboncoeur MA (2009) Ice storm effects on the canopy structure of a northern hardwood forest after 8 years. Can J For Res 39:1475-1483.

Wehner, MF (2004) Predicted twenty-first-century changes in seasonal extreme precipitation events in the parallel climate model. J Climate. 17:42814290.White MA, Nemani RR (2003) Canopy duration has little influence on annual carbon storage in the deciduous broad leaf forest. Glob Change Biol 9:967-972.

Winkler S (2004) A user-written SAS program for estimating temporal trends and their magnitude. Technical Publication SJ2004-4. St. Johns River Water Management District, Palatka, FL.

Wolfe DW, Schwartz MD, Lakso AN, et al. (2005) Climate change and shifts in spring phenology of three horticultural woody perennials in northeastern USA. Int J Biometeorol. 49: 303-309. 
Table 1. Characteristics of the meteorological stations at HBEF and the surrounding region.

Data from HBEF

\begin{tabular}{lrrrr}
\hline $\begin{array}{l}\text { TEMPERATURE } \\
\text { Station }\end{array}$ & Elev. $(\mathbf{m})$ & Aspect & Record & Completeness \\
\hline G1 & 490 & SSE & $1956-2005$ & $>99.99 \%$ \\
G6 & 750 & SSE & $1961-2005$ & $99.96 \%$ \\
G14 & 730 & N & $1965-2005$ & $99.83 \%$ \\
G22 & 250 & -- & $1957-2005$ & $>99.99 \%$
\end{tabular}

SNOW DEPTH AND SOIL FROST

$\begin{array}{lrrr}\text { Station } & \text { Elev. (m) } & \text { Aspect } & \text { Record } \\ \text { G2 } & 560 & \text { SSE } & \text { winters 1955-6 thru 2005-6; six } \\ & & & \text { winters' soil frost data missing }\end{array}$

PRECIPITATION AND STREAMFLOW

\begin{tabular}{lrrrr} 
Station & Elev. $(\mathrm{m})$ & Aspect & Watershed & Record \\
\hline W3 & $530-730$ & SW & 42 ha & $1958-2005$ \\
W7 & $620-900$ & N & 77 ha & $1965-2005$ \\
& & & \\
\multicolumn{2}{l}{ Data from other regional stations } & & & \\
\hline
\end{tabular}

TEMPERATURE

\begin{tabular}{lrrrr} 
Station & Source & Elev. $(\mathbf{m})$ & Record & Completeness \\
\hline Hanover & NCDC & 180 & $1893-2005$ & $98.73 \%$ \\
Pinkham Notch & NCDC & 610 & $1930-2005$ & $98.81 \%$ \\
Mt. Washington & NCDC & 1910 & $1948-2005$ & $99.68 \%$
\end{tabular}

RIVER FLOW

\begin{tabular}{lrrrr} 
Station & Source & Elev. $(\mathrm{m})$ & Watershed & Record \\
\hline Plymouth & USGS & $140-1600$ & $1610 \mathrm{~km}^{2}$ & $1904-2004$
\end{tabular}


Table 2: Climatic metrics examined at HBEF and regionally, with predicted direction of change $(\mathrm{H})$ identified prior to the analysis. Trends are reported for the full length of each record, and also for only the most recent 40 years of data. Trends and $90 \%$ confidence interval limits are reported per decade; " $M$ " indicates that missing data precluded the calculation of a confidence interval. " $T$ " indicates a lack of valid confidence intervals in data sets with a large number of ties and near-zero trends. Slopes in bold differ significantly from 0 ( $p<0.10$; asterisks indicate $p<0.05)$. Shaded cells indicate trends in the hypothesized direction.

\begin{tabular}{|c|c|c|c|c|c|c|c|}
\hline \multirow[b]{2}{*}{ MEAN ANNUAL TEMPERATURE } & \multirow[t]{2}{*}{$\mathbf{H}$} & years & units & \multirow[t]{2}{*}{$\begin{array}{l}\text { full reco } \\
\text { Trend } \\
\text { (units/decade) }\end{array}$} & \multirow[t]{2}{*}{$90 \% \mathrm{Cl}$} & \multicolumn{2}{|c|}{$\begin{array}{l}\text { 1966-2005 } \\
\text { Trend }\end{array}$} \\
\hline & & & & & & & \\
\hline $\mathrm{G} 1$ & + & 50 & $\stackrel{\circ}{ } \mathrm{C}$ & $0.13^{*}$ & $0.03-0.26$ & 0.13 & $-0.01-0.32$ \\
\hline G6 & + & 45 & $\stackrel{\circ}{ } \mathrm{C}$ & 0.13 & $-0.02-0.27$ & $0.19 *$ & $0.01-0.37$ \\
\hline G14 & + & 41 & $\stackrel{\circ}{ } \mathrm{C}$ & $0.32 *$ & $0.17-0.48$ & 0.28 & $0.14-0.46$ \\
\hline $\mathrm{G} 22$ & + & 49 & $\stackrel{\circ}{ } \mathrm{C}$ & $0.24 *$ & $0.16-0.34$ & 0.26 & $0.15-0.41$ \\
\hline Hanover & + & 102 & $\stackrel{\circ}{ } \mathrm{C}$ & $0.12 *$ & $0.09-0.15$ & $0.29 *$ & M \\
\hline Mt. Washington & + & 56 & $\stackrel{\circ}{C}$ & 0.06 & $-0.03-0.16$ & $0.26 *$ & M \\
\hline Pinkham Notch & + & 69 & $\stackrel{\circ}{ } \mathrm{C}$ & -0.04 & $-0.11-0.02$ & $0.25 *$ & M \\
\hline Regional (Mitchell and Jones 2005) & + & 102 & $\stackrel{\circ}{ } \mathrm{C}$ & $0.14 *$ & $0.10-0.18$ & $0.23 *$ & M \\
\hline Global 30-60N (Lugina et al. 2004) & + & 117 & $\stackrel{\circ}{C}$ & $0.07^{*}$ & $0.05-0.08$ & $0.29 *$ & M \\
\hline
\end{tabular}

MEAN SUMMER TEMPERATURE

\begin{tabular}{|c|c|c|c|c|c|c|c|}
\hline G1 & + & 50 & oc & 0.12 & $-0.02-0.27$ & 0.02 & $-0.24-0.23$ \\
\hline G6 & + & 45 & $\stackrel{\circ}{C}$ & $0.23^{*}$ & $0.08-0.40$ & 0.21 & $-0.01-0.40$ \\
\hline G14 & + & 41 & oc & $0.25^{*}$ & $0.07-0.43$ & 0.20 & $0.02-0.39$ \\
\hline $\mathrm{G} 22$ & + & 49 & oc & $0.37^{*}$ & $0.25-0.50$ & $0.33^{*}$ & $0.17-0.49$ \\
\hline
\end{tabular}

MEAN WINTER TEMPERATURE

\begin{tabular}{|c|c|c|c|c|c|c|c|}
\hline G1 & + & 50 & $\stackrel{\circ}{C}$ & $0.38 *$ & $0.11-0.69$ & 0.45 & $0.04-0.87$ \\
\hline G6 & + & 44 & oc & 0.27 & $-0.01-0.56$ & 0.26 & $-0.08-0.62$ \\
\hline G14 & + & 40 & oc & $0.45^{*}$ & $0.09-0.81$ & $0.45^{*}$ & $0.09-0.81$ \\
\hline G22 & + & 48 & $\stackrel{\circ}{C}$ & $0.36^{*}$ & $0.15-0.61$ & $0.31 *$ & $0.07-0.62$ \\
\hline
\end{tabular}

ANNUAL MAXIMUM TEMPERATURE

\begin{tabular}{|c|c|c|c|c|c|c|c|}
\hline G1 & + & 50 & $\stackrel{\circ}{C}$ & 0 & $\mathrm{~T}$ & 0 & $\mathrm{~T}$ \\
\hline G6 & + & 45 & $\stackrel{\circ}{ } \mathrm{C}$ & 0 & $\mathrm{~T}$ & 0 & $\mathrm{~T}$ \\
\hline G14 & + & 41 & oc C & 0 & $\mathrm{~T}$ & 0 & $\mathrm{~T}$ \\
\hline G22 & + & 49 & oc & $0.53^{*}$ & $0.00-0.90$ & $0.71 *$ & $0.00-1.25$ \\
\hline
\end{tabular}

ANNUAL MINIMUM TEMPERATURE

\begin{tabular}{|c|c|c|c|c|c|c|c|}
\hline G1 & + & 50 & oc & 0 & $\mathrm{~T}$ & 0 & $\mathrm{~T}$ \\
\hline G6 & + & 45 & $\stackrel{\circ}{C}$ & 0 & $\mathrm{~T}$ & 0 & $\mathrm{~T}$ \\
\hline G14 & + & 41 & $\stackrel{\circ}{C}$ & $1.25^{*}$ & $0.00-1.91$ & $1.00 *$ & $0.00-1.74$ \\
\hline $\mathrm{G} 22$ & + & 49 & $\stackrel{\circ}{C}$ & 0.27 & $0.00-0.86$ & 0 & $\mathrm{~T}$ \\
\hline \multicolumn{8}{|c|}{ GROWING DEGREE DAYS } \\
\hline G1 & + & 50 & o ${ }^{*}$ days/yr & 20.5 & $-5.6-4.8$ & 12.7 & $-18.6-43.3$ \\
\hline G6 & + & 45 & ó ${ }^{*}$ days/yr & 28.1 & $4.6-52.4$ & $30.9 *$ & $6.4-65.2$ \\
\hline G14 & + & 41 & ó ${ }^{*}$ days/yr & $42.4^{*}$ & $17.9-73.0$ & $35.4^{*}$ & $13.8-64.8$ \\
\hline $\mathrm{G} 22$ & + & 49 & oc*days/yr & $54.2^{*}$ & $30.5-78.0$ & $51.3^{*}$ & $25.3-84.3$ \\
\hline \multicolumn{8}{|c|}{ THAWING DEGREE DAYS (G1) } \\
\hline January and February & + & 50 & oc*days/yr & $2.9^{*}$ & $5.3-16.4$ & 1.96 & $-0.77-5.00$ \\
\hline December - March & + & 49 & o C*days/yr & $10.5^{*}$ & $4.6-52.4$ & $8.82 *$ & $1.37-16.78$ \\
\hline
\end{tabular}


Table 2 continued

\begin{tabular}{|c|c|c|c|c|c|}
\hline & & full re & & 1966 & \\
\hline years & units & $\begin{array}{r}\text { Trend } \\
\text { (units/decade) }\end{array}$ & $90 \% \mathrm{Cl}$ limits & $\begin{array}{r}\text { Trend } \\
\text { (units/decade) }\end{array}$ & $90 \% \mathrm{Cl}$ limits \\
\hline
\end{tabular}

FROST-FREE SEASON (G1)

\begin{tabular}{lllrrrrr}
\hline Last spring frost & - & 50 & date & -1.58 & $-3.33-0.00$ & 0.62 & $-1.94-3.21$ \\
First fall frost & + & 50 & date & $1.92^{*}$ & $0.32-3.33$ & 0 & $T$ \\
Frost-free season & + & 50 & days/yr & $3.75^{*}$ & $0.81-6.57$ & 0 & $T$
\end{tabular}

TOTAL ANNUAL PRECIPITATION

\begin{tabular}{llllrrrr}
\hline W3 & + & 48 & $\mathrm{~mm} / \mathrm{yr}$ & 34.2 & $-3.0-69.4$ & $-34.0-64.9$ \\
W7 & + & 40 & $\mathrm{~mm} / \mathrm{yr}$ & -- & -- & 7.0 & 16.5 \\
\hline
\end{tabular}

SUMMER PRECIPITATION

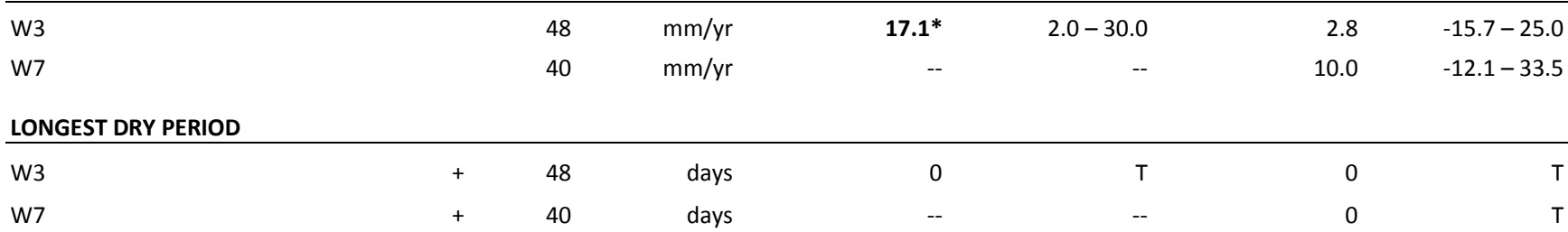

INTENSE PRECIPITATION

\begin{tabular}{|c|c|c|c|c|c|c|c|}
\hline \multicolumn{8}{|l|}{ 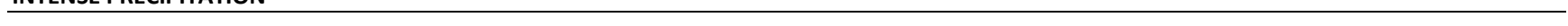 } \\
\hline Days of precipitation $>50 \mathrm{~mm} \mathrm{W3}$ & + & 48 & days/yr & 0 & $\mathrm{~T}$ & 0 & $\mathrm{~T}$ \\
\hline Days of precipitation $>50 \mathrm{~mm} \mathrm{W7}$ & + & 40 & days/yr & -- & -- & 0.33 & $0.00-0.79$ \\
\hline \multicolumn{8}{|l|}{ LOW STREAMFLOW } \\
\hline Days with streamflow $<0.1 \mathrm{~mm}$ at $\mathrm{W} 3$ & + & 48 & days/yr & $-8.74 *$ & $-14.78--4.26$ & -2.50 & $-8.86-4.69$ \\
\hline Days with streamflow $<0.1 \mathrm{~mm}$ at $\mathrm{W} 7$ & + & 40 & days/yr & -- & -- & -1.18 & $-8.39-4.58$ \\
\hline \multicolumn{8}{|l|}{ HIGH STREAMFLOW } \\
\hline Days with streamflow $>50 \mathrm{~mm}$ at $\mathrm{W} 3$ & + & 48 & days/yr & 0 & $\mathrm{~T}$ & 0 & $\mathrm{~T}$ \\
\hline Days with streamflow $>50 \mathrm{~mm}$ at W7 & + & 40 & days/yr & -- & -- & 0 & $\mathrm{~T}$ \\
\hline \multicolumn{8}{|l|}{ EVAPOTRANSPIRATION } \\
\hline W3 & + & 47 & $\mathrm{~mm} / \mathrm{yr}$ & -10.9 & $-19.6--3.5$ & -4.7 & $-14.2-4.0$ \\
\hline W7 & + & 40 & $\mathrm{~mm} / \mathrm{yr}$ & -- & -- & 3.1 & $-3.6-10.0$ \\
\hline \multicolumn{8}{|l|}{ TIMING OF SPRING RUNOFF } \\
\hline W3 & - & 48 & date & $-2.07 *$ & $-3.33--0.35$ & -1.89 & $-3.27-0.61$ \\
\hline W7 & - & 40 & date & -- & -- & $-3.06 *$ & $-5.23--1.04$ \\
\hline Pemigewasset R. at Plymouth & - & 101 & date & -0.29 & $-0.83--0.24$ & -1.92 & M \\
\hline \multicolumn{8}{|l|}{ SNOWPACK DURATION (G2) } \\
\hline First measurable snowpack & + & 51 & date & 1.67 & $-1.08-4.48$ & 3.28 & $-0.48-7.82$ \\
\hline Last measurable snowpack & - & 51 & date & $-2.50^{*}$ & $-4.27--0.83$ & $-5.00 *$ & $-7.33--2.11$ \\
\hline Snowpack duration & - & 51 & days/yr & -4.00 & $-7.39-0.00$ & $-8.60 *$ & $-12.18--4.36$ \\
\hline \multicolumn{8}{|l|}{ MAXIMUM SNOWPACK } \\
\hline G2 & - & 51 & $\mathrm{~mm}$ water & -10.5 & $-21.9-0.0$ & -16.7 & $-31.0--0.9$ \\
\hline \multicolumn{8}{|l|}{ MAXIMUM SOIL FROST ${ }^{\dagger}$} \\
\hline G2 & + & 45 & $\%$ area & $8.8^{*}$ & $2.1-15.6$ & 3.1 & $-8.1-14.3$ \\
\hline
\end{tabular}

tSoil frost statistics are from least-squares linear regression; the non-parametric method was inappropriate due to a large number of ties resulting from years with no soil frost observed. 
Fig. 1. (a) Location of hydrometerologic stations used in this study. (b) Gage 1 at HBEF. Temperature and precipitation data have been collected continually at this location since 1955.
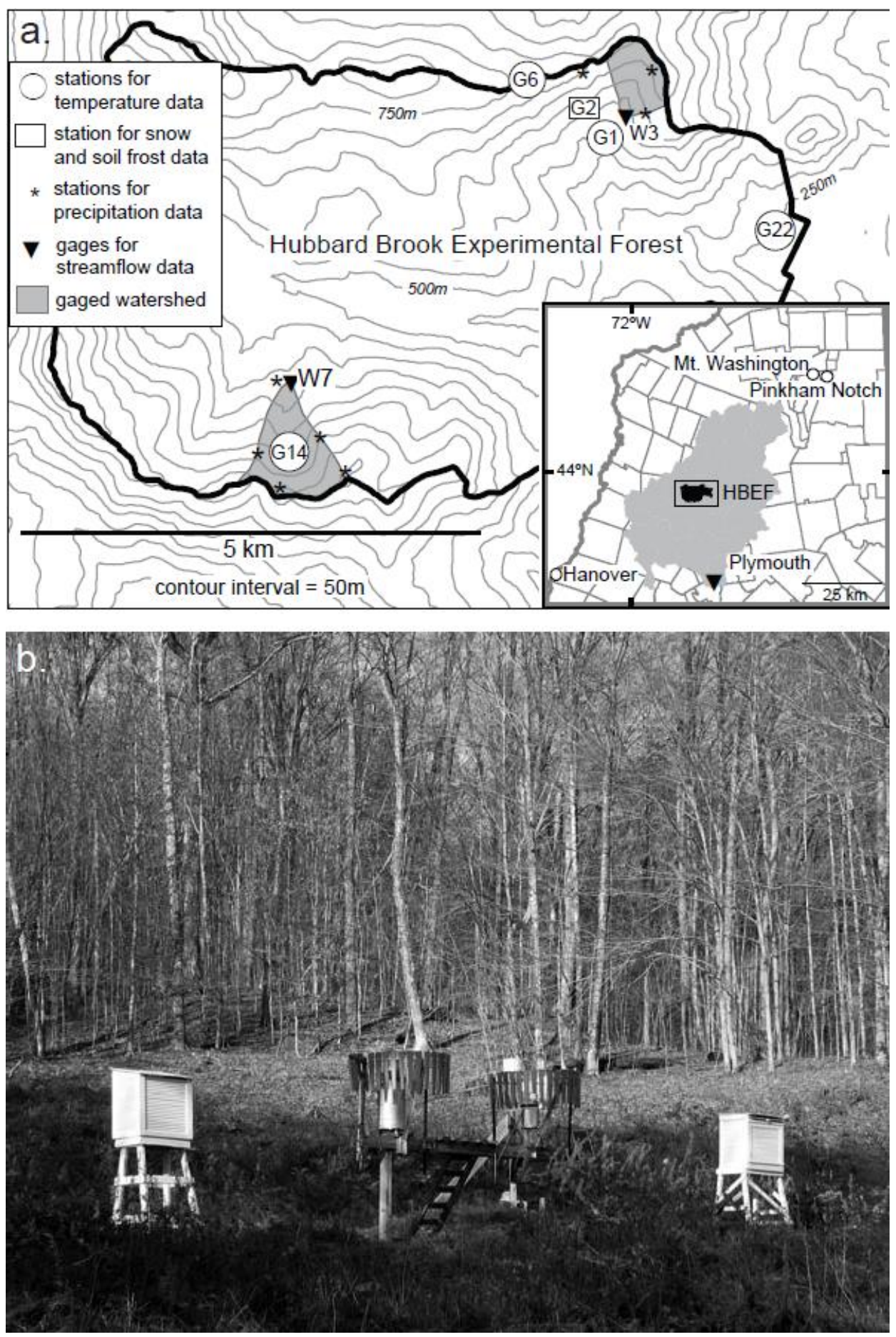
Fig. 2. (a) Mean annual temperature at the four longest-operating stations at HBEF. Differences in temperature among stations are attributable to elevation and aspect (Table 1). All four show significant warming trends. (b) Mean annual temperature at G1 station shows a pattern similar to integrated regional data (Mitchell and Jones 2005) and global data (Lugina et al. 2004).
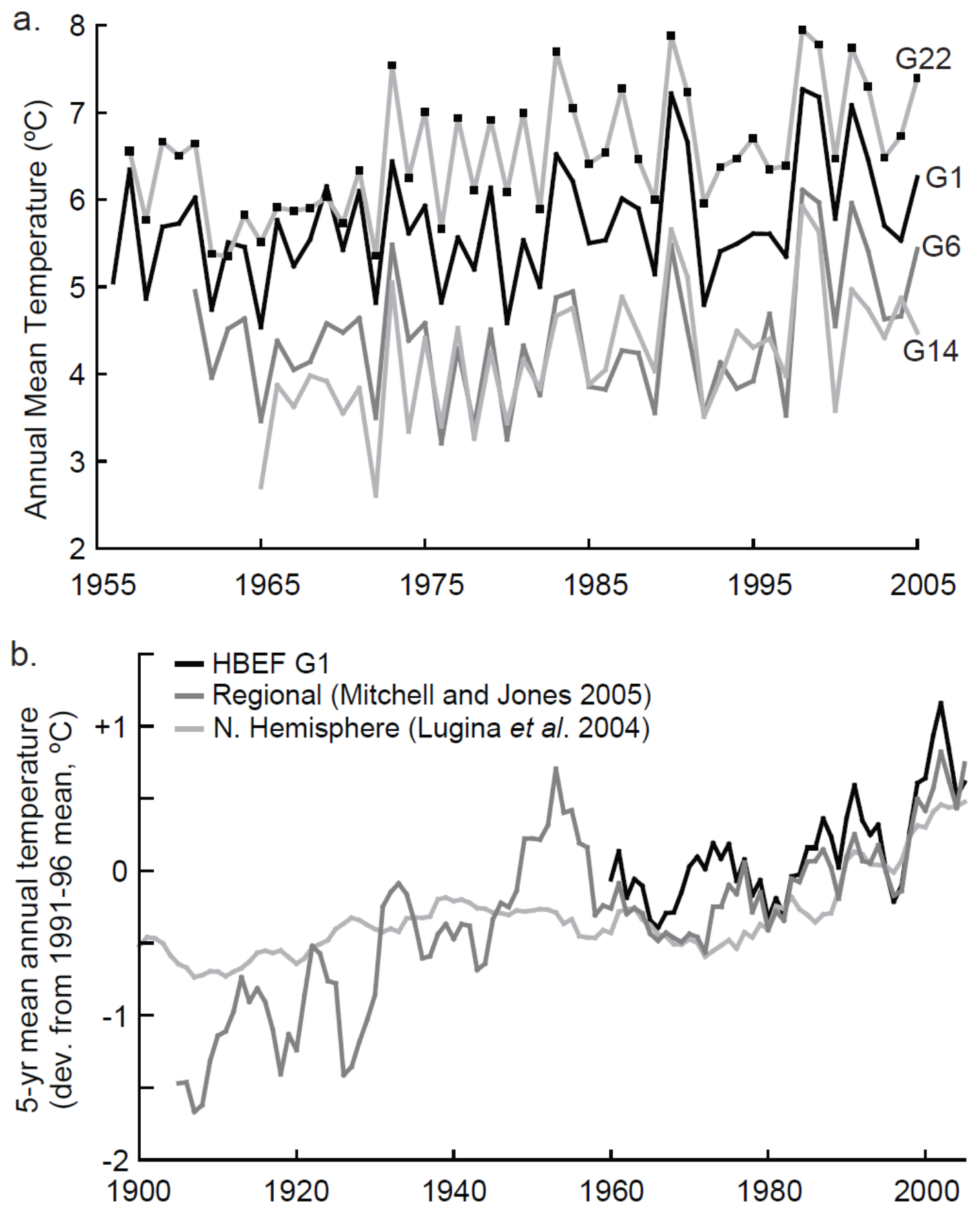
Fig. 3. Thawing degree days at station $\mathrm{G} 1$, have doubled for both the mid-winter months (January and February) as well as the entire winter (December to March).

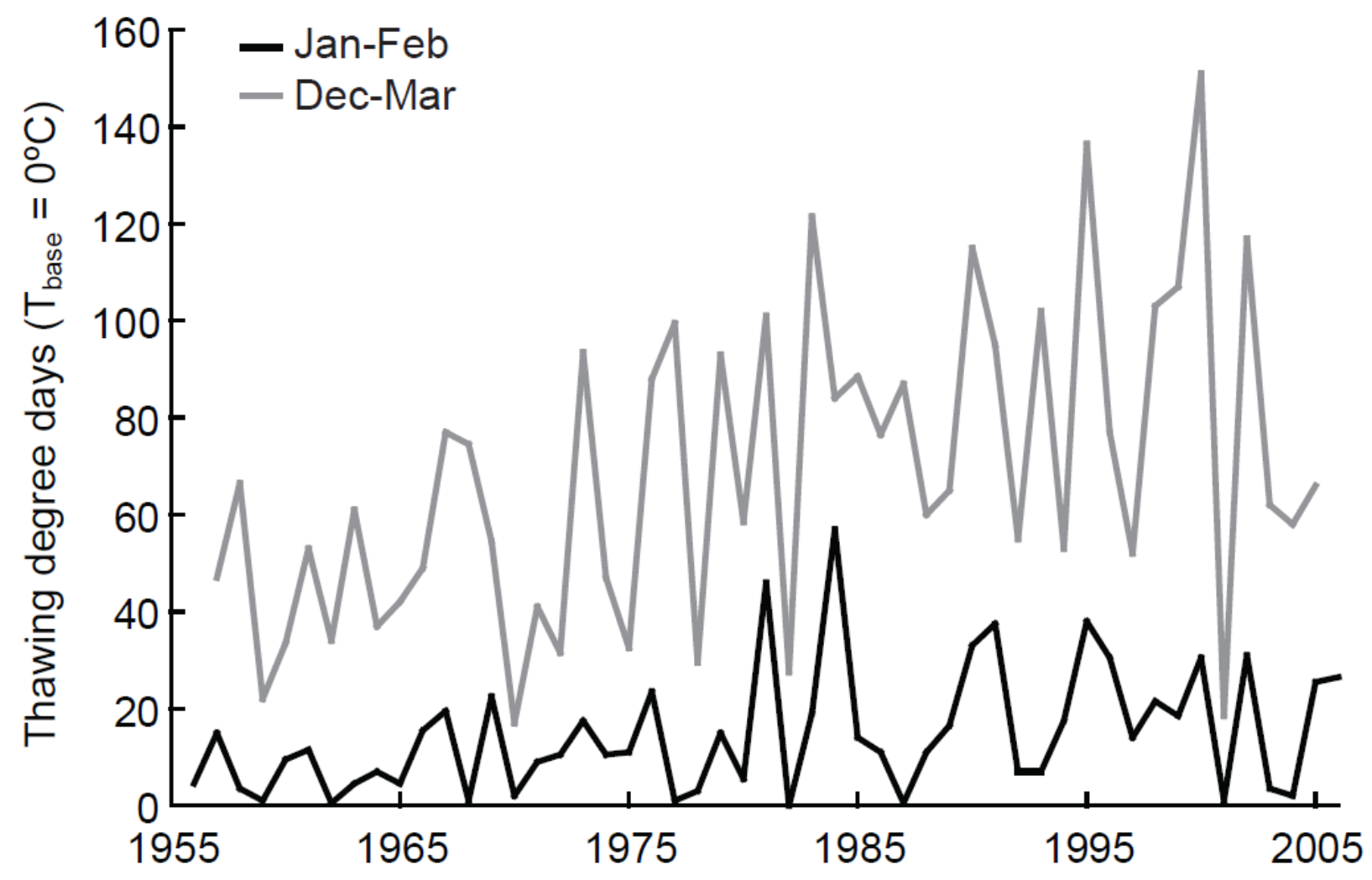


Fig. 4. Date of spring center-of-volume stream flow at W3 (south-facing) and W7 (north-facing). This date is a good indicator of the timing of spring thaw conditions, and occurs 10-12 days earlier now than at the start of the record.

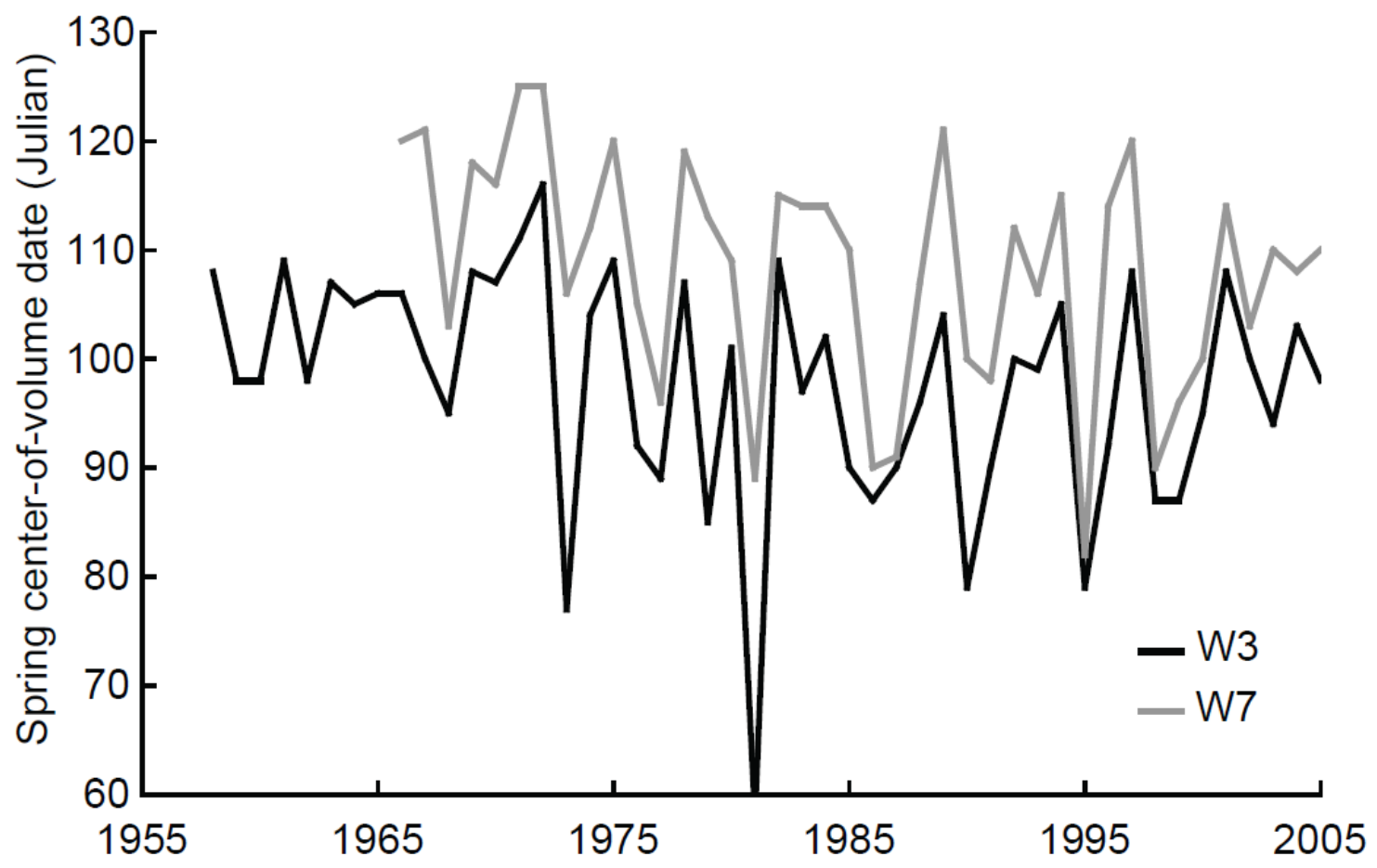


Fig. 5. Frequency analysis of (a) daily mean temperature at $\mathrm{G} 1$ and (b) daily streamflow at W3. The frequency of days in each bin between 1986 and 2005 is expressed as a percentage change from its frequency between 1958 and 1977. Under the null hypothesis of no climate change, we would expect small, non-systematic deviations from the $0 \%$ change line. Extreme cold days have become far less frequent, while extreme hot days have become slightly more frequent. Days of extreme low flow have become far less frequent, while extreme high flows have become more frequent.
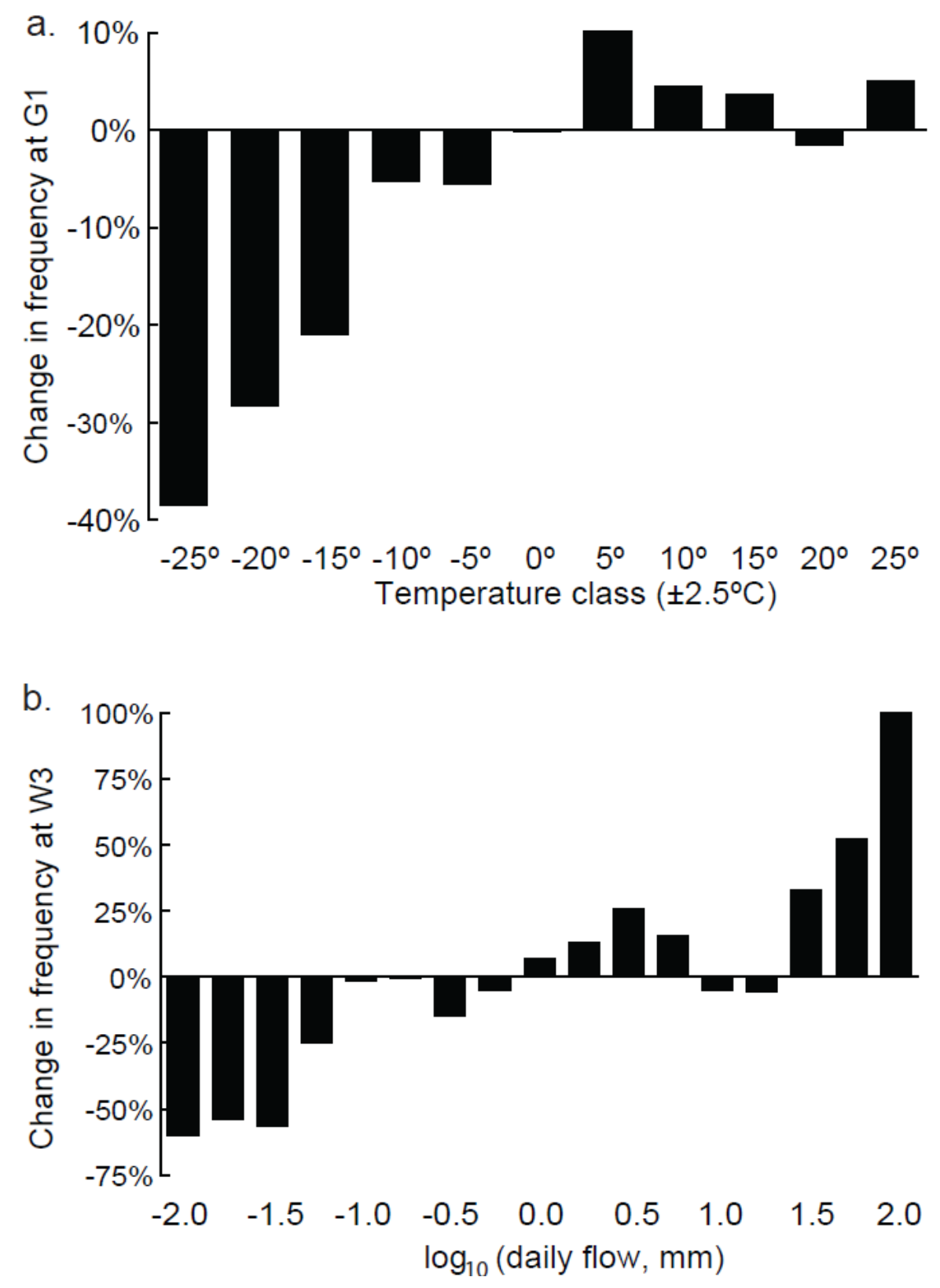